\title{
A CALIBRATION PROCEDURE USING TOPMODEL TO DETERMINE SUITABILITY FOR EVALUATING POTENTIAL CLIMATE CHANGE EFFECTS ON WATER YIELD ${ }^{1}$
}

\author{
Brian C. Dietterick, James A. Lynch, and Edward S. Corbett ${ }^{2}$
}

\begin{abstract}
An evaluation was conducted on three forested upland watersheds in the northeastern U.S. to test the suitability of TOP. MODEL for predicting water yield over a wide range of climatic scenarios. The analysis provides insight of the usefulness of TOP. MODEL as a predictive tool for future assessments of potential long-term changes in water yield as a result of changes in global climate. The evaluation was conducted by developing a calibration procedure to simulate a range of climatic extremes using historical temperature, precipitation, and streamflow records for years having wet, average, and dry precipitation amounts from the Leading Ridge (Pennsylvania), Fernow (West Virginia), and Hubbard Brook (New Hampshire) Experimental Watersheds. This strategy was chosen to determine whether the model could be successfully calibrated over a broad range of soil moisture conditions with the assumption that this would be representative of the sensitivity necessary to predict changes in streamflow under a variety of climate change scenarios. The model calibration was limited to a daily time step, yet performed reasonably well for each watershed. Model efficiency, a least squares measure of how well a model performs, averaged between 0.64 and 0.78 . A simple test of the model whereby daily temperatures were increased by $1.7^{\circ} \mathrm{C}$, resulted in annual water yield decreases of 4 to 15 percent on the three watersheds. Although these results makes the assumption that the model components adequately describe the system, this version of TOPMOD$\mathrm{EL}$ is capable to predict water yield impacts given subtle changes in the temperature regime. This suggests that adequate representations of the effects of climate change on water yield for regional assessment purposes can be expected using the TOPMODEL concept.

(KEY TERMS: model calibration; climate change; forested watersheds; hydrologic modeling; TOPMODEL; water yield.)
\end{abstract}

\section{INTRODUCTION}

Recent research suggests that climatic change brought about by increasing levels of greenhouse gases in the atmosphere will increase global temperatures (Cannell et al., 1989) and affect spatial and temporal patterns of precipitation (Wolock, 1993; Yarnal, 1990). Estimates of the magnitude of potential climate changes from Global Circulation Models (GCMs) are uncertain (Joyce et al., 1990). Many may argue that the evidence available still does not support that global climate change will occur. However, researchers that support various climate change scenarios agree that these changes would alter temperature and moisture regimes of many regional climates. These changes, in turn, could affect evapotranspiration, precipitation, and soil moisture storage and ultimately, the timing and magnitude of runoff, lake levels, and groundwater availability. Planning for management and use of forest and water resources will depend on our ability to accurately predict the effects of physical climate change on hydrologic cycles, particularly from forested watersheds because approximately 80 percent of the surface runoff is yielded from forested and wildland watersheds. For these reasons an investigation of methods for evaluating impacts on regional water resources is warranted.

Hydrologic models that provide reliable water yield estimates over a wide range of watershed conditions under a variety of climatic scenarios are needed to evaluate the impacts of climate change on water resources. From a hydrologic point of view, the most important predicted changes in physical climate as a result of climate change are changes in precipitation and temperature, both of which affect evapotranspirational processes and ultimately water availability. Consequently, model development or selection should

\footnotetext{
2Respectively, Assistant Professor of Watershed Management, Natural Resources Management Department, California Polytechnic State University San Luis Obispo, California 93407; Professor of Forest Hydrology, School of Forest Resources, Penn State University, University Park, Pennsylvania 16802; and Hydrologist (retired), USDA Forest Service, Northeastern Forest Experiment Station, University Park, Pennsylvania 16802 (
} 
include components that consider evapotranspirational processes, soil moisture storage opportunities, and precipitation patterns under a variety of vegetative conditions. The model should also consider the variable nature of hydrologic processes and be applicable to a wide variety of watersheds. One such model that addresses many of these requirements is TOPMODEL, a basin hydrologic model for predicting stormflow responses to a time series input of precipitation and temperature (Beven and Kirkby, 1979).

Other studies have shown a reasonable degree of success in calibrating TOPMODEL to a small watershed in the Shenandoah Mountains (Hornberger et $a l ., 1985$ ), and for three small watersheds in the United Kingdom (Beven et al., 1984). Ambroise et al. (1996) used a modified TOPMODEL and showed similar calibration success for a watershed in a small mountainous watershed in France. One recent study, however, found difficulty in validating TOPMODEL on a Swiss catchment using field-estimated parameters and observed that the physical processes of the catchment were not adequately being represented by TOPMODEL (Iorgulescu and Jordan, 1994). A point remains uncertain is what constitutes a legitimate calibration or validation, particularly in light of the variability in hydrologic response as a function of model time step, watershed size, and parameter quantification.

The objective of this study was to test whether TOPMODEL could be calibrated over a broad range of soil moisture and precipitation regimes on three watersheds from different physiographic regions having different vegetative, lithologic, and topographic characteristics that result in a wide range of hydrologic responses. TOPMODEL was selected for this study because of the previous success by others and the versatility of the model to reflect the physical processes occurring on forested upland watersheds in the northeastern United States. Evaluating model performance over a broad range of soil moisture and precipitation conditions is intended to encompass precipitation changes that may be possible from climate change. A successful calibration over this broad range of physical conditions and physiographic regions implies that TOPMODEL would be a viable model for estimating regional water yield impacts on upland forested watersheds throughout the northeastern United States using a number of climate change scenarios.

\section{STUDY LOCATIONS}

Three upland forested watersheds in the northeastern U.S. were selected for the model simulations.
These include: Fernow Four (F4), Hubbard Brook Three (HB3), and Leading Ridge One (LR1) Experimental Watersheds. The watershed locations are shown in Figure 1. The watersheds were selected primarily because they are located in different physiographic regions, are completely forested, and have different hydrologic regimes. As the "control" watersheds for these study areas, detailed climatic and watershed data are available. All three watersheds experience similar climatic patterns. However, the further north the watershed location the more wintry the climate. The climate of the northeastern United States is a humid, continental type. Frontal systems are the dominant source of precipitation. Tropical storms occasionally affect the study sites and can cause heavy rainfall. Orographic influences on precipitation are also experienced at each of the sites.

\section{Fernow Four (F4)}

F4 is 39.2 hectares in area and is located on the Fernow Experimental Forest in the Appalachian Plateau physiographic province of West Virginia. The watershed is at $39^{\circ} 03^{\prime} \mathrm{N}$ latitude and $79^{\circ} 42^{\prime} \mathrm{W}$ longitude in northeastern West Virginia. F4 has an eastern aspect and ranges in elevation from $740 \mathrm{~m}$ to $868 \mathrm{~m}$. Streamflow is measured using a broad-crested weir with a 90-degree, v-notch inset. Precipitation was measured using a Belfort weighing-type raingage. Average annual precipitation for F4 is $1458 \mathrm{~mm}$. Temperature was measured using a Belfort hygrothermograph. Average annual temperature for $\mathrm{F} 4$ is $9^{\circ} \mathrm{C}$, and mean monthly temperatures range from $-4^{\circ} \mathrm{C}$ to $19^{\circ} \mathrm{C}$.

The soils are predominately inceptisols characteristically well-drained, medium-textured loam and silt loam residual soils ranging in depth from one to several meters. These soils formed through the weathering of underlying acid shales and sandstone. The vegetative cover is predominantly an oak forest with beech, sugar maple, and yellow poplar.

\section{Hubbard Brook Three (HB3)}

HB3 is 42.4 hectares in area and is located on the Hubbard Brook Experimental Forest in the New England physiographic province of New Hampshire. The watershed is at $43^{\circ} 56^{\circ} \mathrm{N}$ latitude and $71^{\circ} 45^{\prime} \mathrm{W}$ longitude in the southwestern corner of the White Mountains of northcentral New Hampshire. HB3 has a southern aspect and ranges in elevation from $416 \mathrm{~m}$ to $717 \mathrm{~m}$. Streamflow is measured using a 90-degree, $v$-notch weir. Precipitation is measured using a Belfort weighing-type raingage. Average annual 


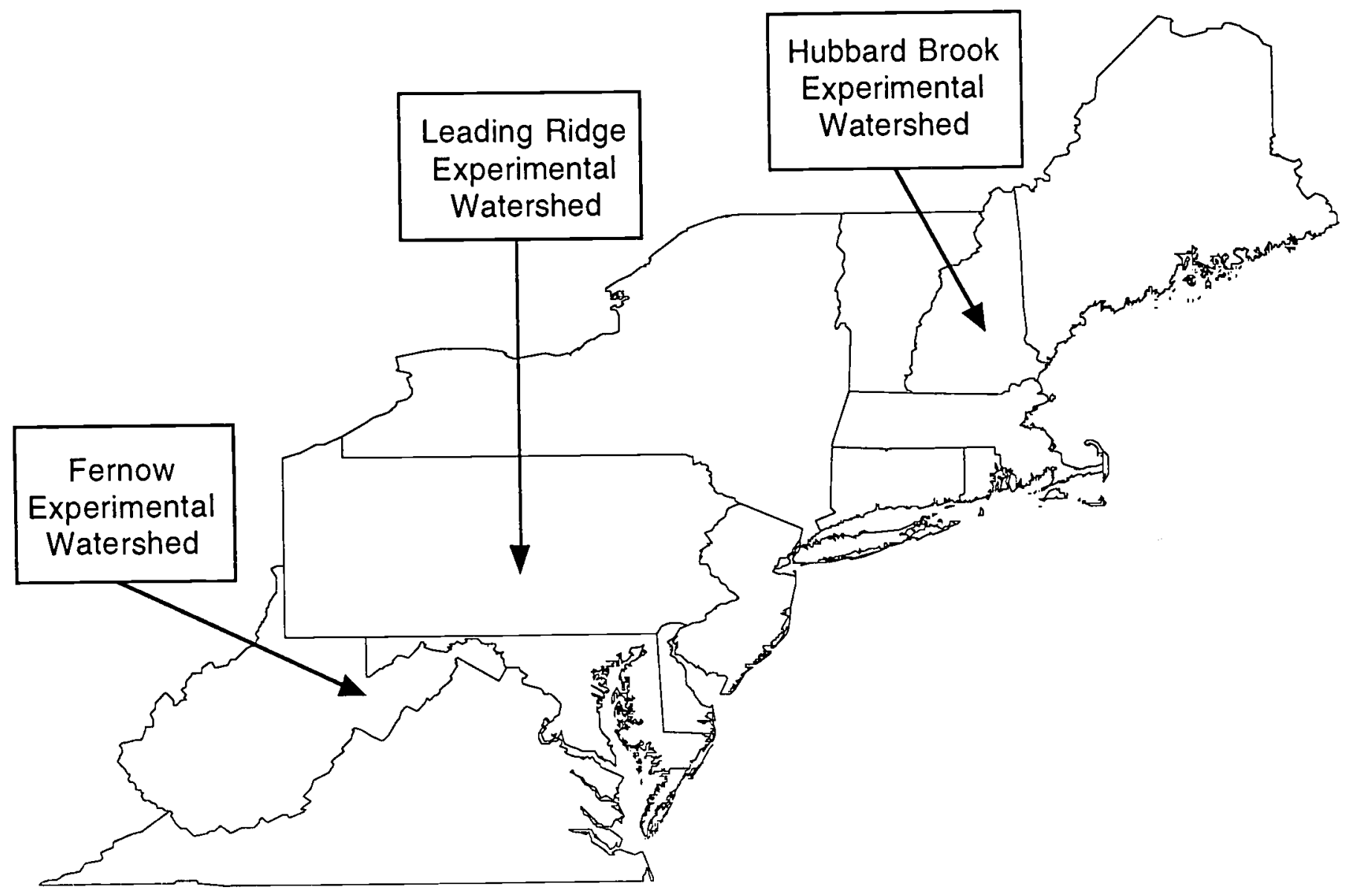

Figure 1. Locations of Fernow Four (F4), Hubbard Brook Three (HB3), and Leading Ridge One (LR1) Experimental Watersheds.

precipitation for HB3 is $1388 \mathrm{~mm}$. Temperature was measured using a Belfort hygrothermograph. Average annual temperature for $\mathrm{HB} 3$ is $6^{\circ} \mathrm{C}$, and mean monthly temperatures range from $-9^{\circ} \mathrm{C}$ to $18^{\circ} \mathrm{C}$.

The soils are derived from glacial till to form typical spodisol soils ranging in depth from zero to several meters. The vegetative cover is a mature, second growth northern hardwood forest, which is dominated by sugar maple, beech, and yellow birch. Balsam fir and red spruce occur primarily at higher elevations.

\section{Leading Ridge One (LR1)}

LR 1 is 122.7 hectares in area and is located in the Valley and Ridge physiographic province of central Pennsylvania. LR 1 is at $40^{\circ} 40^{\circ} \mathrm{N}$ latitude and $77^{\circ} 57 \mathrm{~W}$ longitude and has a southeastern aspect and ranges in elevation from 275 meters to 450 meters. Stream discharge is monitored using a modified broad-crested trenton weir with a sharp-crested, 90-degree, v-notch in the center. Precipitation was measured at a single station using a Belfort weighingtype raingage. Average annual precipitation for LR1 is $1064 \mathrm{~mm}$. Temperature was measured using a Belfort hygrothermograph. Average annual temperature for LR 1 is $11^{\circ} \mathrm{C}$, and mean monthly temperatures range from $0^{\circ} \mathrm{C}$ to $23^{\circ} \mathrm{C}$.

The soils are residual ranging in depth from one to several meters formed on colluvial material through the weathering of underlying shales and sandstone. The vegetative cover consists of an uneven-aged, coppice forest of oak, hickory, and maple.

\section{APPROACH}

\section{TOPMODEL Overview}

TOPMODEL is a physically-based model that includes typical components of most conceptual watershed-scale models. In addition, TOPMODEL includes the distinction that the model simulates the 
variable source area (VSA) concept of streamflow generation (Hewlett and Hibbert, 1967). Incorporating the VSA concept in to a hydrologic model is not unique to TOPMODEL. It is the concept of streamflow generation recognized by most wildland hydrologists, but is not recognized universally by all hydrologists, nor has it been incorporated into most watershed-scale models. The TOPMODEL concept was developed in the late 1970s (Beven and Kirkby, 1979), and later developed into a watershed-scale model which has undergone numerous revisions to the model structure to meet the needs and interests of other investigators (Beven et al., 1984; Famiglietti, 1992; Famiglietti and Wood, 1991; Hornberger, et al., 1985; Piñol et al., 1997; Wolock and Hornberger, 1991; Wolock, 1988; Wolock et al., 1989; Wood et al., 1988). Much of the current research centers around improving the performance of the model through investigations of sensitivity of model parameters and structure. Ambroise et al. (1996) has shown that alternative forms of the model structure, based on alternative transmissivity functions, can improve model performance, particularly during low streamflow periods. The representiveness of rainfall input data, namely storm volumes, has been found to be influential on model performance, even though expanding the gage network did not improve model efficiencies (Obled et al., 1994). Others have focused on the effects of DTM (digital terrain model) scale in deriving the topographic index, $\ln (a / \tan \beta)$ and the sensitivity of this index and other parameters on model output (Franchini et al., 1996; Quinn et al., 1991; Saulnier et al., 1997; Wolock and Price, 1994). Much attention has also focused on assessing uncertainty in model predictions resulting in the development and application of the GLUE (Generalized Likelihood Uncertainty Estimation) methodology for estimating uncertainty bounds for these predictions (Beven and Binley, 1992; Fisher and Beven, 1996; Binley et al., 1991). Wolock and Hornberger (1991) successfully used TOPMODEL to evaluate the hydrological effects of doubling atmospheric carbon dioxide levels. Band et al. (1993) coupled a distributed ET (evapotranspiration) model with TOPMODEL. This effort demonstrated watershed ET variability in modeling soil moisture status on forested ecosystems. Piñol et al. (1997) found that by altering or adding to the model structure of TOPMODEL that some improvement in model efficiency can be obtained. Freer et al. (1997) demonstrated that the topographic index may not be adequately represented solely by surface topography emphasizing the importance of other controls such as the influence of local geologic structure and soil hydraulic properties on flow pathways.
There are many notable differences that exist among different formulations. One of the most significant differences are between formulations that utilize statistics of the frequency distribution of the topographic index, $\ln (a / \tan \beta)$ and those that utilize the spatially distributed values of the index. Similarly, lumped parameter values and spatially-distributed parameter values are used with these approaches, respectively. Both approaches assume that the spatial distribution of $\ln (a / \tan \beta)$ approximates the spatial distribution of the depth to the water table in a watershed. This is an important factor to approximate the dynamic hydrologically-active source areas typically found at the base of concave hillsides. Differences in predictions of total streamflow using both approaches have been shown to be negligible (Wolock, 1995). A more in-depth discussion of TOPMODEL can be found in Beven (1997), Beven et al. (1984), and Wolock, (1993).

A TOPMODEL formulation, reported by Wolock (1988), that utilizes the statistical distribution of the $\ln (a / \tan \beta)$ was used in this study. In this version, the watershed is partitioned into areas defined by classes of the spatial distribution of $\ln (a / \tan \beta)$, where " $a$ " is the watershed area contributing to a point and $\tan \beta$ is the steepest slope about that point. This model approach was selected because data necessary to parameterize soil hydraulic characteristics are not available on a spatially distributed scale for the three study watersheds. In addition, TOPMODEL was cho. sen because it simulates a variable source area approach to streamflow generation and includes hydrologic processes that are consistent with the forested watersheds used in this analysis.

This version of TOPMODEL (herein referred to as TOPMODEL) includes typical components found in most conceptual basin-scale models for forested watersheds. Infiltrating water is stored within the soil profile. At any point in the watershed, water can drain downslope at a rate dependent on the depth to saturation, the hydraulic conductivity of the soil, and a parameter describing the exponential increase in hydraulic conductivity the closer the saturated zone is to the land surface. Overland flow can also occur on areas in which the entire soil profile is saturated. Hydrologically-active areas within the watershed are defined typically at topographically convergent areas at the bases of slopes as a function of $\ln (a / \tan \beta)$ and the current hydrologic condition of the soil. Water can be withdrawn from the soil at its potential rate by evapotranspiration. The evapotranspiration routine included in this version of TOPMODEL is based on the Hamon formula (Hamon, 1961). This empirical method utilizes air temperature data and latitude to yield saturation vapor pressure and daytime hours to predict potential evapotranspiration. 
TOPMODEL Parameters and Output

A number of soil and topographic parameters along with watershed latitude and a time series of precipitation and air temperature are required to run TOPMODEL. Table 1 lists required input parameters and expected model output.

TABLE 1. TOPMODEL Inputs and Outputs (Wolock, 1993).

INPUTS

\begin{tabular}{|c|c|}
\hline Time Series of: & $\begin{array}{l}\text { Precipitation } \\
\text { Temperature } \\
\text { Observed Streamflow }\end{array}$ \\
\hline \multicolumn{2}{|l|}{ Topography (DEM data) } \\
\hline $\begin{array}{l}\text { Spatial Distributions of } \\
\text { Soil Characteristics: }\end{array}$ & $\begin{array}{l}\text { Hydraulic Conductivity } \\
\text { Depth to Bedrock } \\
\text { Depth of AB Soil Horizon } \\
\text { Field Capacity }\end{array}$ \\
\hline \multicolumn{2}{|l|}{ Latitude } \\
\hline \multicolumn{2}{|l|}{ Watershed Area } \\
\hline \multicolumn{2}{|c|}{ OUTPUTS } \\
\hline Time Series of: & $\begin{array}{l}\text { Total streamflow } \\
\text { Subsurface flow }\end{array}$ \\
\hline $\begin{array}{l}\text { Temporal and Spatial } \\
\text { Distributions of: }\end{array}$ & $\begin{array}{l}\text { Overland Flow } \\
\text { Depth to Water Table } \\
\text { Saturated Land-Surface Area } \\
\text { Soil Moisture } \\
\text { Evapotranspiration }\end{array}$ \\
\hline
\end{tabular}

\section{Parmeterization and Calibration}

Model performance is evaluated using the objective function, model efficiency. Model efficiency is defined as:

$$
\begin{aligned}
\text { Model Efficiency }= & (1 \text {-variance of the data }) / \\
& \text { (1-variance of the residuals })
\end{aligned}
$$

A model efficiency of one indicates the model is performing perfectly, whereas a model efficiency of zero indicates the model is performing no better than the mean of the observed data.

A parameter optimization routine (Rosenbrock, 1960 ) is included in TOPMODEL for calibration purposes. The optimization routine performs numerous iterations on selected parameter estimates which are adjusted in attempts to maximize the objective function. Parameter optimization is preferred by many modelers because minimum time and effort is involved and maximum model efficiencies are often achieved. For this study, initial estimates were made for those parameters that could not be quantified with reasonable certainty given the existing data. The Rosenbrock optimization technique was used along with trial and error parameter adjustments to obtain the "best fit" for calibration.

The "drivers" of the model include time series of precipitation and temperature for each of the years for which the model is calibrated. One additional year was also needed to allow the internal state variables to be initialized and equilibrated. The model was calibrated for above average (wet), average, and below average (dry) precipitation years. An above average year was selected if it met the criteria of having 10 percent greater than average precipitation and the increases were evenly distributed based on mean monthly precipitation. An average precipitation year was selected if the monthly distribution was consistent with average monthly amounts. Below average years were selected if the year had 10 percent less precipitation and the reduction was distributed evenly based on mean monthly precipitation. This criteria was chosen to represent a full range of possible changes to the precipitation regimes due to climate change. Assuming an evenly-distributed increase or decrease in precipitation is speculative, yet this method will generate a broad range of hydrologic conditions under which to test the model for each of the watersheds and to evaluate the potential for TOPMODEL to be used for further evaluations of regional impacts on water yields from forested watersheds in the northeastern United States.

Derivation of most soil and geographic parameters was accomplished using published and unpublished site documentation (M. B. Adams, 1992, Personal Communication, USDA Northeastern Forest Experiment Station, Parsons, West Virginia; Adams et al., 1994; E. J. Ciolkosz, 1991, Personal Communication, Soil Characterization Laboratory, Penn State University, University Park, Pennsylvania; C. A. Federer, 1992, Personal Communication, USDA Northeastern Forest Experiment Station, Durham, New Hampshire; Federer et al., 1990, J. Hudak, 1992, Personal Communication, USDA SCS, University Park, Pennsylvania; Lynch and Corbett, 1985; USDA, 1987), using empirical methods for estimating soil hydraulic conductivity by Stevens (1988), Portland State University (Wolock, 1988) and then deriving spatiallyweighted averages using GIS software, ARC/INFO and ERDAS. Due to uncertainty in estimating lumped values for some soil hydraulic parameters, such as 
hydraulic conductivity, field capacity, and soil depth, these parameters were estimated initially and then optimized during the calibration process.

The first three moments of the spatial distribution for the topographic index, $\ln (a / \tan \beta)$ were computed using 7.5-minute DEMs. These values are summarized for each watershed in Table 2 and reveal that topographic differences exist between the watersheds.

TABLE 2. Statistics of the $\ln (a / \tan \beta)$ Distributions for Leading Ridge One, Fernow Four, and Hubbard Brook Three Using 7.5-Minute DEMs.

\begin{tabular}{cccc}
\hline \multirow{2}{*}{ Watershed } & \multicolumn{3}{c}{ Statistic of $\ln (\mathbf{a} / \tan \beta)$ Distribution } \\
\cline { 2 - 4 } & Mean & Variance & Skew \\
\hline LR1 & 6.13 & 1.66 & 2.08 \\
F4 & 6.56 & 2.32 & 6.19 \\
HB3 & 6.15 & 2.64 & 5.90 \\
\hline
\end{tabular}

Results

Simulations were performed using wet, dry, and average precipitation years to calibrate TOPMODEL for the Leading Ridge One, Hubbard Brook Three, and Fernow Four watersheds. Model efficiencies ranging between 0.64 and 0.78 were achieved indicating the model predicted discharge values $64-78$ percent better than the mean of the observed data. Model efficiencies for the wet, dry, and average years were 0.76 , 0.64 , and 0.68 for Leading Ridge One; $0.71,0.78$, and 0.75 for Fernow Four; and $0.64,0.75$, and 0.76 for Hubbard Brook Three, respectively. These model efficiency results were all within the range reported by Beven et al. (1984) for year-long calibrations of three U.K. watersheds. Franchini et al. (1996) reported model efficiencies greater than .90 over three-month periods using an hourly time step while evaluating the sensitivity of the model.

Although the model efficiency results are favorable, a closer inspection of the entire time series of observed versus predicted discharges (Figures 2 through 4), indicates periods of disparity throughout the calibration period. The disparity in the observed versus predicted discharges can be attributed to the inability of the model to adequately reflect antecedent soil moisture conditions that affect the magnitude of subsequent runoff events.

Five possible explanations were identified that may account for the inability of the model to accurately predict soil moisture conditions. These include: (1) an inability of the model to predict snow accumulation or snowmelt accurately, particularly during late winter and early spring; (2) baseflow was consistently overestimated during low flow months (June through October), suggesting possibly that ET is being underestimated or simply because there is no allowance for basin leakage, or because there is not an interception component within this version of the model; (3) erroneous parameter estimates that influence soil moisture storage (soil depth, field capacity) and soil hydraulic properties (hydraulic conductivity, percent of macropore flow, and slope); (4) the representativeness of one raingage for each watershed may be limiting the accuracy of the volume of incoming rainfall; and (5) a model time step that is inappropriate for describing the hydrological processes of the watershed. It is possible that any or all of the factors can be limiting model performance.

The time series of observed versus simulated discharges suggest that antecedent conditions preceding runoff events are overestimated causing erroneous streamflow responses. This occurred most often during times when average daily temperature values were in the vicinity of $0^{\circ} \mathrm{C}$ suggesting the inability of a daily time step to accurately predict rain or snow events and snowmelt. This may be due to inherent problems predicting snow accumulation/snowmelt using a daily model time step. Mean daily temperature may not be adequate for predicting whether precipitation events occur as rain or snow, nor is it adequate for accurate predictions of the occurrence and magnitude of snowmelt on these watersheds when mean daily temperatures are in the vicinity of $0^{\circ} \mathrm{C}$.

A goal of this study was to evaluate TOPMODEL for use in evaluating regional impacts on water yield. Available data for driving the model for a large number of watersheds would likely be limited to daily data. Thus, calibrations using a finer time step were not investigated. Snowpack ripening and the subsequent release of meltwater or the occurrence of rain on snow in upland forested watersheds is a formidable task, particularly when a daily time step is used. Other snowmelt models face similar problems when modeling snow accumulation and snowmelt using a daily time step for watersheds of this scale. Thus, incorporating an alternative snowmelt model would not be expected to significantly improve the model fit for these watersheds, and was not examined further.

To evaluate the possibility that the ET (evapotranspiration) model (Hamon method) used in this version of TOPMODEL is limiting model performance, daily values of ET during the growing season were increased incrementally. Surprisingly, the high. est model efficiencies were achieved when growing PET (potential evapotranspiration) estimates were 


\section{Leading Ridge One}
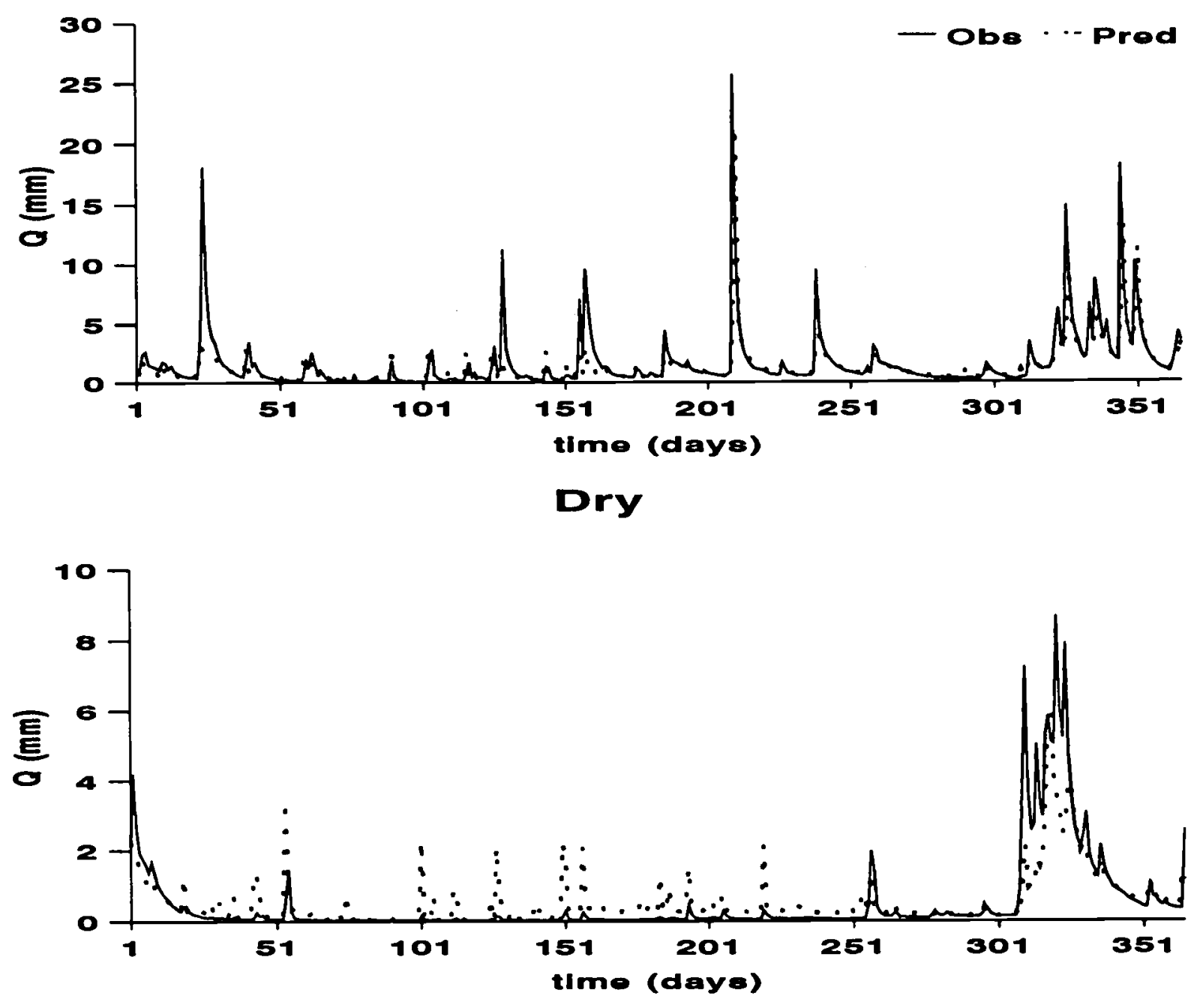

Average

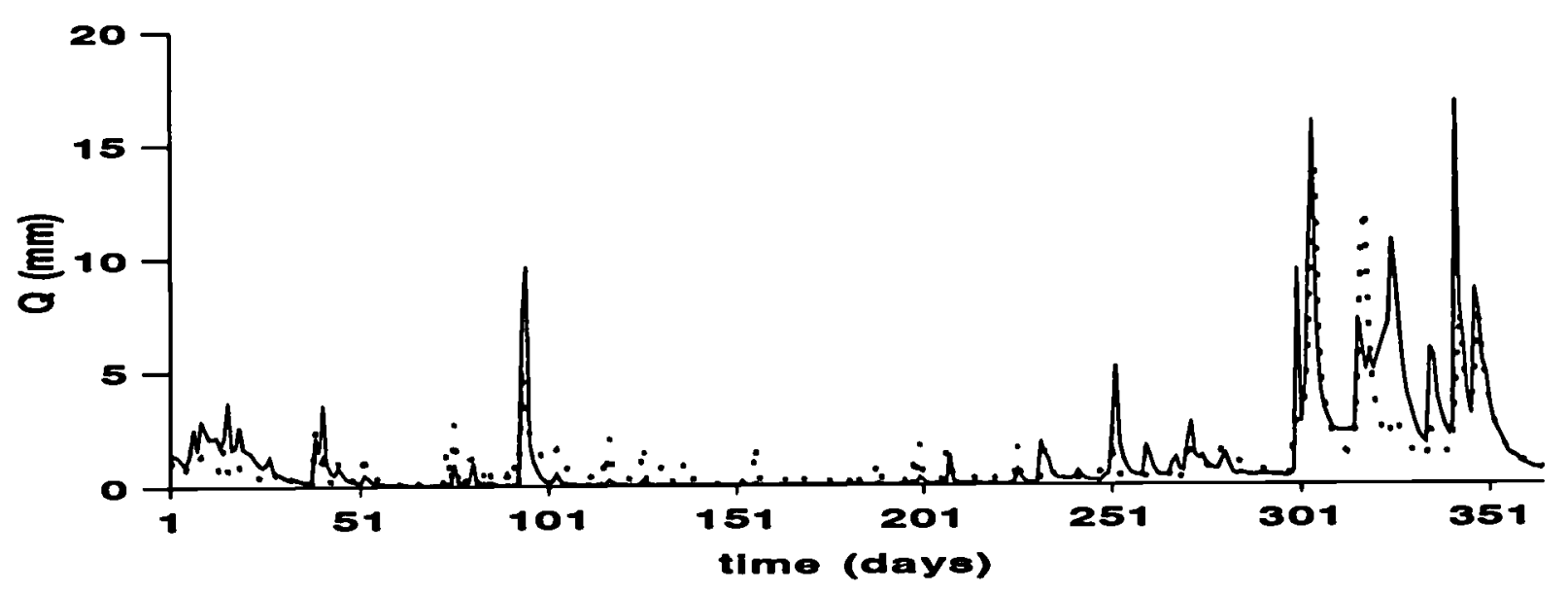

Figure 2. Observed vs. Predicted Stream Discharges for Leading Ridge One. 


\section{Fernow Four \\ wet}

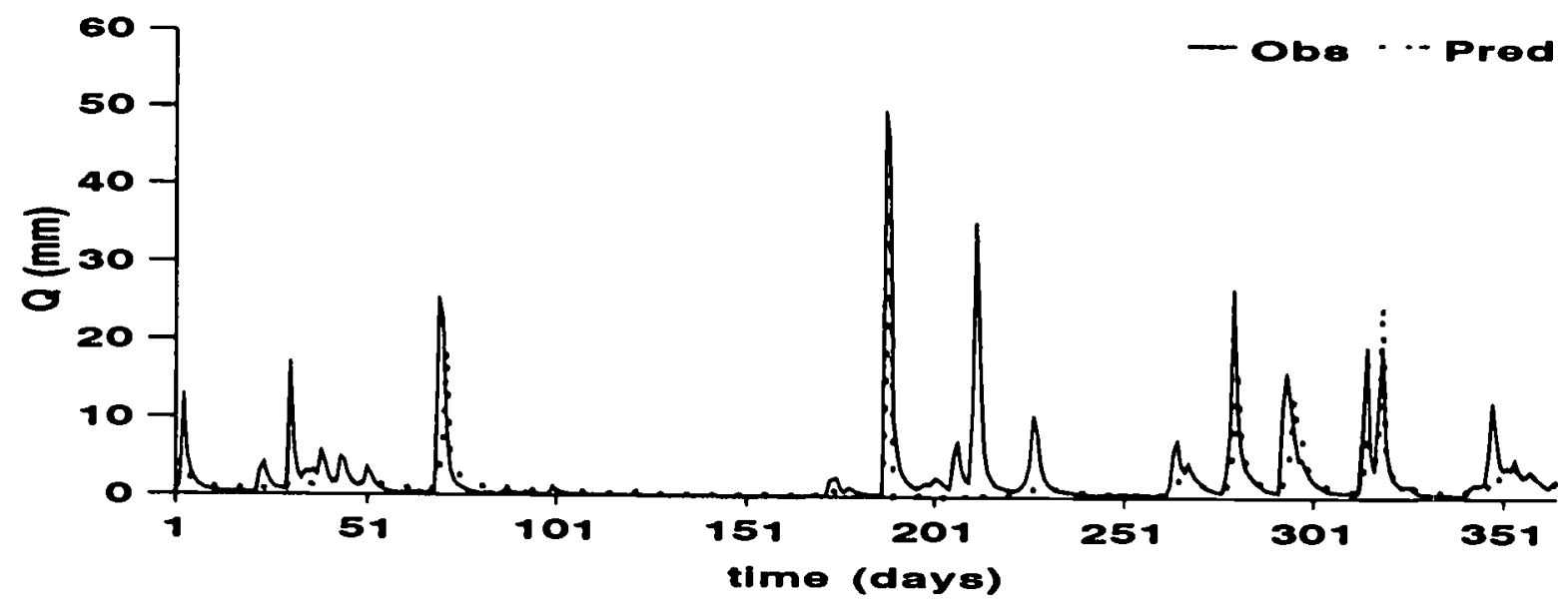

Dry

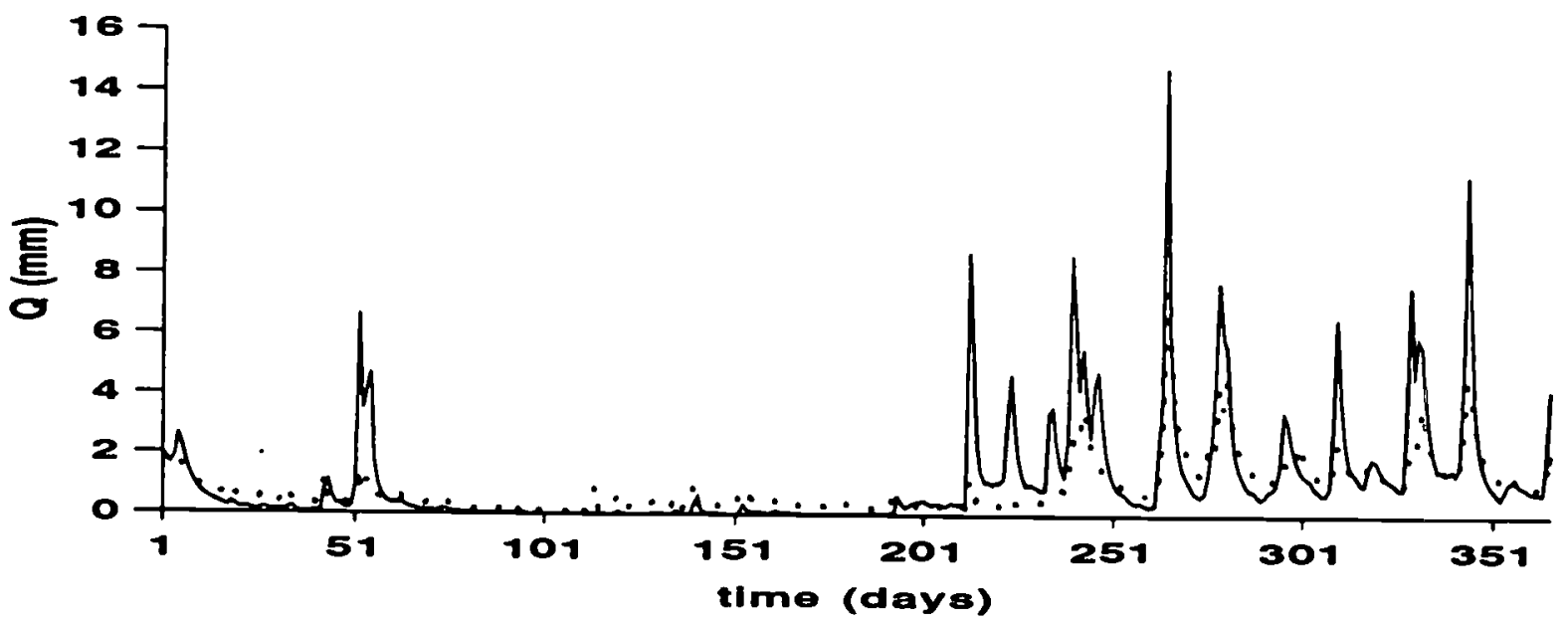

Average

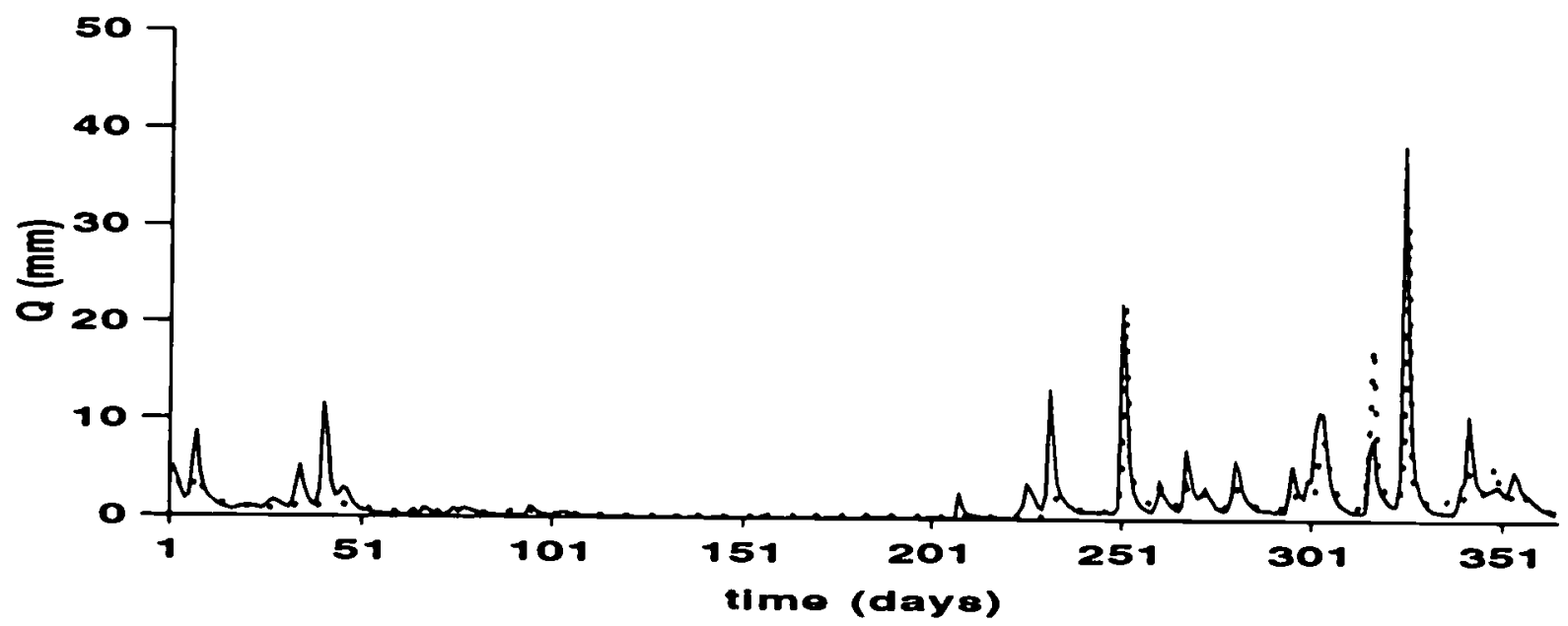

Figure 3. Observed vs. Predicted Stream Discharges for Fcrnow Four. 


\section{Hubbard Brook Three Wet}


Figure 4. Observed vs. Predicted Stream Discharges for Hubbard Brook Threc. 
increased by approximately 100 percent. This was particularly evident for the Leading Ridge watershed. Model efficiencies greater than 0.75 were achieved consistently after increasing daily PET estimates during the growing season by 100 percent. In a climatological sense, this doubling of growing season PET is not warranted and may suggest other factors such as leakage or groundwater outflows that are not included in this version of the model may be contributing. A leakage component was added and found to improve efficiencies similar to those experienced after increasing PET. Although this analysis is inconclusive, it is suspected that the daily model time step is also affecting PET estimates and limiting model performance.

A simplistic exercise was performed to illustrate TOPMODEL's ability to detect changes in water yield that may result from an increase in temperature and subsequent effects on evapotranspiration, and ultimately soil moisture content and water yield. For this analysis all daily temperatures were increased by $1.7^{\circ} \mathrm{C}$. A three-degree Fahrenheit $\left(1.7^{\circ} \mathrm{C}\right)$ temperature increase is consistent with some global warming estimates, but of course, increasing all daily temperatures uniformly by $1.7^{\circ} \mathrm{C}$ is a very simplistic scenario. Annual, growing season, and dormant season water yields after increasing daily temperatures by $1.7^{\circ} \mathrm{C}$ were compared with modeled water yields for the same years using the actual daily temperature values. This analysis assumes that the optimal parameter sets derived during model calibration reasonably describe hydrologic pathways for these watersheds such that relative comparisons can be made using water yield changes that result from an increase in daily air temperatures.

The simulations showed average decreases in water yield during the growing season of 14.9 percent, 10.0 percent, and 8.8 percent for LR1, F4, HB3, respectively. For the dormant season the water yield decreases were 10.7 percent, 4.3 percent, and 4.5 percent for LR1, F4, and HB3. The results of these simulations are presented in Table 3 by comparing water yields for annual, growing season, and dormant season water yield totals, and the percentage decreases following temperature increases. These results show that changes in the average daily air temperature are detectable, assuming the model is calibrated accurately and the ET and other components of the model are performing satisfactorily. What cannot be defined is the degree of accuracy in water yield decreases due to a $1.7^{\circ} \mathrm{C}$ increase in daily air temperatures.

\section{CONCLUSIONS AND RECOMMENDATIONS}

Quantifying the impact on water resources of a variety of possible climate change scenarios is essential if water resource managers are to meet the

TABLE 3. Comparison of Predicted Water Yields (mm) Using Actual Versus $+1.7^{\circ} \mathrm{C}$ Temperaturcs.

\begin{tabular}{|c|c|c|c|c|c|c|c|c|c|}
\hline Watershed & $\begin{array}{l}\text { Annual } \\
\text { (actual) }\end{array}$ & $\begin{array}{l}\text { Annual } \\
\left(+1.7^{\circ} \mathrm{C}\right)\end{array}$ & $\begin{array}{l}\text { Percent } \\
\text { Change }\end{array}$ & $\begin{array}{l}\text { Growing } \\
\text { (actual) }\end{array}$ & $\begin{array}{l}\text { Growing } \\
\left(+1.7^{\circ} \mathrm{C}\right)\end{array}$ & $\begin{array}{l}\text { Percent } \\
\text { Change }\end{array}$ & $\begin{array}{c}\text { Dormant } \\
\text { (actual) }\end{array}$ & $\begin{array}{c}\text { Dormant } \\
\left(+1.7^{\circ} \mathrm{C}\right)\end{array}$ & $\begin{array}{l}\text { Percent } \\
\text { Change }\end{array}$ \\
\hline \multicolumn{10}{|c|}{ Wet } \\
\hline LRI & 537 & 474 & -11.8 & 127 & 113 & -10.9 & 410 & 361 & -12.0 \\
\hline F4 & 716 & 677 & -5.6 & 167 & 141 & -15.6 & 549 & 536 & -2.5 \\
\hline HB3 & 883 & 835 & -5.3 & 311 & 279 & -10.3 & 571 & 556 & -2.6 \\
\hline \multicolumn{10}{|c|}{ Dry } \\
\hline LR1 & 199 & 183 & .8 .0 & 57 & 51 & -10.3 & 142 & 132 & .7 .0 \\
\hline$F_{4}$ & 337 & 315 & -6.7 & 69 & 66 & -4.8 & 269 & 249 & -7.2 \\
\hline HB3 & 350 & 341 & -2.5 & 80 & 75 & -6.7 & 270 & 266 & -1.3 \\
\hline \multicolumn{10}{|c|}{ Average } \\
\hline LR1 & 390 & 329 & -15.6 & 97 & 74 & -23.5 & 294 & 256 & -13.0 \\
\hline$F_{4}$ & 545 & 519 & -4.8 & 115 & 104 & -9.7 & 429 & 415 & -3.3 \\
\hline HB3 & 571 & 516 & -9.5 & 118 & 106 & -9.5 & 453 & 410 & -9.6 \\
\hline \multicolumn{10}{|c|}{ Mean } \\
\hline LR 1 & & & -11.8 & & & -14.9 & & & -10.7 \\
\hline F4 & & & -5.7 & & & -10.0 & & & -4.3 \\
\hline HB3 & & & -5.8 & & & -8.8 & & & -4.5 \\
\hline
\end{tabular}


growing demands for potable water. The TOPMODEL modeling concept is a viable means for future studies to predict long-term effects of climatic change on streamflow from small, forested upland watersheds of the northeastern U.S. After using this calibration procedure, TOPMODEL appears capable of detecting differences in water yield under a broad range of climatic and physiographic conditions. This infers the model is suitable for evaluating potential water yield impacts under various climatic change scenarios throughout the northeastern United States. However, the results using a daily time step suggest that impacts on annual water yields, as opposed to monthly water yield impacts, would be most reliable.

The model results revealed some difficulty in describing antecedent soil moisture conditions that led to subsequent difficulties predicting the magnitude of the hydrologic response. This was evident in defining whether a precipitation event was either rain or snow and timing and magnitude of snowmelt. During the growing season there were some difficulties estimating the magnitude of runoff that also can be attributed to antecedent moisture conditions possibly through the ET component of the model. The inability of the model to adequately describe soil moisture conditions during certain periods of the year may suggest alternative snowmelt or ET components be used. However, similar results with these model components replaced would be expected when a daily time step is used. This study limited the model evaluation to a daily time step because daily data would likely be available for future regional assessments of water yield impacts due to climate change. A preliminary evaluation showed that model performance could also be improved upon by incorporating other components, such as leakage and groundwater outflow. Certainly other factors such as the quality of the input data or the accuracy of the optimized parameter sets can all affect model performance. Given these potential impacts on model calibration, it can still be stated that TOPMODEL performed reasonably well.

Furthermore, calibrating TOPMODEL using wet, dry, and average years over a variety of physiographic settings has been demonstrated as an approach for approximating a variety of climatic conditions indicative of a range of potential climate change scenarios in the northeastern United States. The exercise whereby daily temperatures were increased by 1.7 degrees Celsius, demonstrated that the model is sensitive enough to detect changes in annual water yield. Impacts on monthly water yield would be less accurate, but annual water yield changes seem to be predicted reasonably well. These results suggest that TOPMODEL would be applicable for future assessments to predict annual water yield changes for forested watersheds in the northeastern United States under a variety of climatic change scenarios.

\section{ACKNOWLEDGMENTS}

This study was supported by the U.S. Forest Service, Northeastern Forest Experiment Station (Cooperative Agreement No. 23-755) through their Northern Global Change Research Program. We wish to thank Dave Wolock, Tony Federer, Mary Beth Adams, and Jim Kochenderfer who have contributed information and provided insight to this project.

\section{LITERATURE CITED}

Adams, M. B., J. N. Kochenderfer, F. Wood, T. Angradi, and P. Edwards, 1994. Forty Years of Hydrometeorological Data from the Fernow Experimental Forest, West Virginia. Gen. Tech. Rep. NE-184, USDA Northeastern Forest Experiment Station, Radnor, Pennsylvania, 24 pp.

Ambroise, B., K. Beven, and J. Freer, 1996. Toward a Generalization of the TOPMODEL Concepts: Topographic Indices of Hydrological Similarity. Water Resour. Research 32(7):2135-2145.

Band, L. E., P. Patterson, R. Nemani, and S.W. Running, 1993. Forest Ecosystem Processes at the Watershed Scale: Incorporating Hillslope Hydrology. Agric. and Forest Metcorology 63:93126.

Beven, K., 1997. TOPMODEL: A Critique. Hydrological Processes 11:1069-1085.

Beven, K. and M. J. Kirkby, 1979. A Physically-Based, Variable Contributing Area Model of Basin Hydrology. Hydro. Sci. Bull. 24:43-69.

Beven, K. J. and A. Binley, 1992. The Future of Distributed Models: Model Calibration and Uncertainty Prediction. Hydrol. Proc. 6(3):279-298

Beven, K. J., M. J. Kirkby, N. Schoficld, and A. F. Tagg, 1984. Testing a Physically.Based Flood Forecasting Model (TOPMODEL) for Three U.K. Catchments. J. Hydro. 69:119-143.

Binley, A. M., K. J. Beven, A. Calver, and L. G. Watts, 1991. Changing Responses in Hydrology: Assessing the Uncertainty in Physically Based Model Predictions. Water Resour. Rescarch 27(6):1253-1261

Cannell, M. G. R., J. Grace, and A. Booth, 1989. Possible Impacts of Climatic Warming on Trees and Forests in the United Kingdom: A Review. Forestry 62(4):337-364

Famiglietti, J. S., 1992. Aggregation and Scaling of SpatiallyVariable Hydrologic Processes: Local, Catchment-Scale and Macroscale Models of Water and Energy Balance. Ph.D. Dissertation, Dept. of Civil Eng. and Operations Res., Princeton University, Princeton. New Jersey.

Famiglietti, J. S. and E. F. Wood, 1991. Evapotranspiration and Runoff from Large Land Areas: Land Surface Hydrology for Atmospheric General Circulation Models. Surv. of Geophys. 12:179-204.

Federer, C. A., L.D. Flynn, C.W. Martin, J. W. Hornbeck, and R. S. Pierce, 1990. Thirty Years of Hydrometeorologic Data at the Hubbard Brook Experimental Forest, New Hampshire. Gen. Tech. Rep. NE-141, USDA Northeastern Forest Experiment Sta. tion, Radnor, Pennsylvania, $44 \mathrm{pp}$.

Fisher, J, and K.J. Beven, 1996. Modelling of Streamflow at Slapton Wood Using TOPMODEL Within an Uncertainty Estimation Framework. Ficld Studies 8:577-584. 
Franchini, M. J., J. Wendling, C. Obled, and E. Todini, 1996. Physical Interpretation and Sensitivity Analysis of the TOPMODEL. J. Hydro. 175:293-338.

Freer, J., J. McDonnell, K. J. Beven, D. Brammer, D. Burns, R. P. Hooper, and C. Kendal, 1997. Topographic Controls on Subsurface Storm Flow at the Hillslope Scale for Two Hydrologically Distinct Small Catchments. Hydrological Processes 11:1347. 1352.

Hamon, W. R., 1961. Estimating Potential Evapotranspiration. J. Hydraulics Div., Proc. Am. Soc. Civ. Eng. 87(3):107-120.

Hewlett, J. D. and A. R. Hibbert, 1967. Factors Affecting the Response of Small Watersheds to Precipitation in Humid Areas. International Symp. For. Hydrol., 275-290, Pergamon Press, New York, New York.

Hornberger, G. M., K. J. Beven, B. J. Cosby and D. E. Sappington, 1985. Shennandoah Watershed Study: Calibration of a Topography-Based, Variable Contributing Area Hydrological Model to a Small Forested Catchment. Water Resour. Res. 21:1841-1850.

Iorgulescu, I. and J.-P. Jordan, 1994. Validation of TOPMODEL on a Small Swiss Catchment. J. Hydro. 159:255-273.

Joyce, L. A., M. A. Fosberg, and J. M. Comanor, 1990. Climate Change and America's Forests. USDA Forest Service, Rocky Mountain Forest and Range Experiment Station, Fort Collins, Colorado, Gen. Tech. Rep. RM-187, 12 pp.

Lynch, J. A. and E. S. Corbett, 1985. Source Area Variability During Peakflow: A Function of Antecedent Soil Moisture Content. Proc. Symp. Watershed Mgmt./ Irrigation Drainage Div., ASCE, April 30-May 1, Denver, Colorado.

Obled, C., J. Wendling, and K. Beven, 1994. The Sensitivity of Hydrological Models to Spatial Rainfall Patterns: An Evaluation Using Observed Data. J. Hydro. 159:305-333.

Piñol, J., K. Beven, and J. Freer, 1997. Modelling the Hydrological Response of Mediterranean Catchments, Prades, Catalonia. The Use of Distributed Models as Aids in Hypothesis Formulation. Hydrological Processes 11:1287-1306.

Quinn, P. F., K. Beven, P. Chevallier, and O. Planchon, 1991. The Prediction of Hillslope Flow Paths for Distributed Hydrological Modelling Using Digital Terrain Models. Hydrological Processes, 5:50-79, John Wiley and Sons, Ltd.

Rosenbrock, H. H., 1960. An Automatic Method for Finding the Greatest or Least Value of a Function. Computer J. 3:175-184.

Saulnier, G. M., C. Obled, and K. Beven, 1997. Analytical Compensation Between DTM Grid Resolution and Effective Values of Saturated Hydraulic Conductivity Within the TOPMODEL Framework. Hydrological Processes 11:1331-1346.

Stevens, D., 1988. In: Topographic and Soil Hydraulic Control of Flow Paths and Soil Contact Time: Effects on Surface Water Acidification, D.M. Wolock, Ph.D. dissertation, Univ. of Virginia, p. 50

USDA, 1987. Forest Research: Fernow Experimental Forest. NEINF-75-87, USDA Forest Service Northeastern Folest Experiment Station, Radmor, Pennsylvania, 24 pp.

Wolock, D. M., 1988. Topographic and Soil Hydraulic Control of Flow Paths and Soil Contact Time: Effects on Surface Water Acidification. Ph.D. Dissertation, Univ. of Virginia, May 1988.

Wolock, D.M., 1993. Simulating the Variable-Source-Area Concept of Streamflow Generation With the Watershed Model TOPMODEL. USDI Geological Survey, Lawrence, Kansas, 62 pp.

Wolock, D. M., 1995. Effects of Subbasin Size on Topographic Characteristics and Simulated Flow Paths in Sleepers River Watershed, Vermont. USDI Geological Survey, Lawrence, Kansas.

Wolock, D. M., G. M. Hornberger, K. J. Beven, and W. G. Campbell, 1989. The Relationship of Catchment Topography and Soil Hydraulic Characteristics to Lake Alkalinity in the Northeast. ern United States. Water Resour. Res. 25:829-837.
Wolock, D. M. and G. M. Hornberger; 1991. Hydrological Effects of Changes in Atmospheric Carbon Dioxide Levels. J. Forecasting 10:105-116

Wolock, D. M. and C. V. Price, 1994. Effects of Digital Elevation Model Map Scale and Data Resolution on a Topography-Bascd Watershed model. Water Resour. Resenrch 30(11):3041-3052.

Wood, E. F., M. Sivapalan, K. J. Beven, and L. Band, 1988. Effects of Spatial Variability and Scale With Implications to Hydrologic Modeling. J. Hydrol. 102:29-47

Yarnal, B., 1990. Past and Future Climatic Trends - Consequences on Water Resources Planning and Decision Making. In: Water Resources in Pennsylvania: Availability, Quality, and Management, S. K. Majumdar, E. W. Miller and R. R. Parizck (Editors). Pennsylvania Academy of Science, Easton, Pennsylvania, pp. $30-40$. 